\title{
Contemporary Urban Russian Funerals: Continuity and Change
}

\author{
Jeanmarie Rouhier-Willoughby \\ University of Kentucky
}

\begin{abstract}
Про похороны интереснее рассказывать, потому что в похоронном обряде сохранились традиции глубже всего. Потому что тут, какими бы ни были люди далекими от всего, образованными, страшными консерваторами, тут надо все соблюсти.

It is more interesting to talk about funerals because, in the funerary ritual, traditions have been preserved best of all. Because here, no matter how far people were from everything, whether educated, whether frightfully conservative, here everything has to be observed.
\end{abstract}

So said Ekaterina Z., an informant from Novosibirsk, born in 1978. While Ekaterina's opinion has some merit, as we will see, the urban Russian funeral has not been a stable ritual throughout the 20th and 21st centuries. In fact, it reflects attitudes from both the Soviet period and the post-Soviet period, attitudes which demonstrate how social values have changed over these periods. This paper is based on thirty interviews about funerals with residents of Novosibirsk and Vladimir, Russia (or with emigres to America). The informants ranged in age from 26 to 73 years of age and included 25 women and 5 men. 27 were Russian; the remaining three identified themselves as Tatar, Bashkir or Mordvin. They are representatives of the urban working and middle classes; most attended VUZy (institutions of higher education). 17 were from Novosibirsk and 13 from Vladimir. Most of the funerals they described took place in those locations between 1966 and 2003, although one funeral took place in Chita. In order to evaluate the validity of Ekaterina's statement, we must first examine the traditional $19^{\text {th }}$ century village funeral.

Funerals were of four types: for a man (the most elaborate); for a married woman (least elaborate); for an unmarried woman (essentially a wedding ceremony) and for children [Mahler 1935]. Below we will discuss the funeral for married adults, as this ritual provides the full range of ritual acts that will be essential to an understanding of the Russian funeral in the contemporary period. Elderly people generally prepared their burial clothing before they died [Kremleva 2003: 520; Sedakova 242]. Burial clothing included a typical folk costume, but was easily distinguished from what was worn in life by color and in some 
cases, design. It was important that the clothing be new and unworn or freshly washed (if not new) [Baiburin 108; Ananicheva and Samodelova 189]. When a person died, candles were lit and all the mirrors in the house were covered, and all water was thrown out, since it was believed that water and mirrors (symbolically similar to water due to their reflective nature) might trap the soul on this earth, which would result in unquiet or restless dead [Baiburin 105; Kabakova 261; Zelenin 349]. Typically married women (not relatives) washed and dressed the body and wrapped it in a white shroud, leaving only the head and hands uncovered; they were paid with cloth or with items of clothing that belonged to the deceased [Nosova 104; Sedakova 242; Kremleva 1993: 13; Kabakova 258]. As part of the process of preparing the body, they closed the deceased's eyes and covered them with coins and often tied the feet and hands [Baiburin 106, 108; Sedakova 248]. The materials used to wash the body were thrown away; the water was poured where no one would walk [Nosova 104; Zelenin 346; Sedakova 249; Kremleva 1993: 14].

The deceased remained in the house for three days, lying on the table under the icon corner, with the feet facing the door and head beneath the icons [Zelenin 347; Kremleva 2003: 521; Baiburin 110; Ananicheva and Samodelova 189; Firsov and Kiseleva 287]. During the vigil, nothing was taken out of the house and no cleaning was performed [Nosova 111]. Relatives and friends visited to say farewell, typically bringing a candle along [Kremleva 2003: 521]. A glass of water or vodka covered with bread or a blin were placed near the icons; in some regions, a saucer of water was also located there for the soul to "wash" [Kremleva 2003: 521; Zelenin 345; Sedakova 244; Firsov and Kiseleva 288].

The deceased's female relatives (or invited "sitters") maintained a vigil over the body and ensured that the lamp at the head of the deceased remained lit during the entire vigil; no one was allowed to sleep with a corpse in the house [Sedakova 243; Kremleva 2003: 522]. The coffin was not made by family members. Typically the family asked a priest or deacon to come and bless the coffin with holy water and incense before they placed the deceased into it [Kremleva 2003: 522]. The deceased was put in the coffin on the day of burial, and items placed in the coffin for the deceased to use in the land of the dead included a cross and/or icon, candles, a ceremonial axe (received by boys at birth), pipe, tobacco, money, food (and vodka for men), extra clothing, venik 'birch besom' (for use in the bathhouse), and work implements associated with the deceased's trade [Nosova 113; Kremleva 2003: 522; Sedakova 81; 
Baiburin 111; Firsov and Kiseleva 287]. The candle lit his way to the land of the dead; the money could buy his passage, while the food sustained him on the journey; the clothing and work implements were necessary to live in the otherworld. The folk perceived existence in the land of the dead to be just like life on earth. To function in this world, the deceased would need things similar to those required on earth, such as a pipe and axe [Kabakova 256].

During the vigil, older female relatives would sing laments and read prayers [Kremleva 2003: 521, 522; Baiburin 110]. Families also hired "readers" and professional lamenters for this purpose [Kremleva 1993: 12; Zelenin 355]. The lamenters, generally widows, guided the ritual and led the singing, since they were familiar with the ritual songs required to ensure that the soul made the proper passage to the land of the dead. In fact, older women generally fulfilled many roles in the funeral, from sitters, to lamenters, to those who prepared the body [Sedakova 108]. Laments often included information about the man's life and death, an attack on him for leaving his family, and a laudatory section about his qualities as a father, son, husband, worker, etc. [Kremleva 1993: 13].

When the corpse was removed from the house for burial on the third day, those attending the funeral first carried out the lid, then the priest exited, followed by the coffin itself. People usually removed the coffin via the back door or a window [Moyle 229-230; Nosova 117]. This practice not only helped to prevent the threshold from being tainted by the corpse, but also helped to prevent the corpse from returning to the house. The tracks of the funeral train were swept away, again to help prevent the deceased's return. The coffin was placed on benches outside the house so that those not going to the funeral could say farewell [Firsov and Kiseleva 288]. Generally a few neighbors (older, married women) stayed behind to clean the house and remove the "traces" of death the corpse left behind. They swept and washed the floor, and the table and benches where the deceased had been placed; all the materials used for this purpose were destroyed or thrown away [Ananicheva and Samodelova 190; Sedakova 244, 250; Kremleva 2003: 524; Kabakova 260; Firsov and Kiseleva 288]. These women typically inverted the tables and benches before washing them, so that death would enter the soil [Tolstoi 120]. The priest also said a prayer of purification after the deceased had been carried out [Ananicheva and Samodelova 190]. These same women prepared for the funeral feast that took place after burial. 
The women lamented as the funeral procession proceeded to the church for the otpevanie 'funeral mass' [Kremleva 1993: 18]. In some regions, the path was strewn with fir branches [Surkhasko 93]. At the church, the priest sang the funeral mass; an additional service at graveside was optional [Kabakova 264; Kremleva 1993: 19; 2003: 523]. At the graveside, attendees kissed the deceased farewell, and the coffin was nailed shut; either at the graveside or before removal from the house, the deceased's hands and feet were untied [Baiburin 111]. Funerals usually occurred around noon, when the sun was high in the sky [Nosova 123; Kremleva 2003: 522]. As was the case with preparing the body for burial and making the coffin, non-family members dug the grave [Sedakova 244, 250]. Limitations also existed on who lowered the body into the grave. Zelenin [350] notes that parents did not lower the coffins of their children; nor did children lower their parents. The coffin was lowered on towels or ropes; the towels were sometimes distributed to pallbearers and gravediggers [Kremleva 2003: 523]. Those present typically threw coins into the grave (to buy a space for the deceased in the graveyard or in the other world) and each threw some dirt onto the coffin as the grave was being filled [Baiburin 114; Nosova 124; Kabakova 265; Sedakova 250; Kremleva 2003: 523]. Everyone waited until the grave was filled and, in certain regions, a commemorative meal at the graveside was held [Kremleva 1993: 20]. Elsewhere this meal (with food left for the deceased) occurred on the second day after burial [Sedakova 244].

After the burial, the pominki 'wake' for all those present at the funeral (and often for the entire village) was held at the deceased's home, often in shifts to accommodate all the attendees [Baiburin 117; Nosova 126; Kabakova 266; Firsov and Kiseleva 288]. The meal had to include the following items: bliny, kisel' 'a fruit drink made of cranberries or oats', kut'ia 'grain and raisins sweetened with honey' and kasha 'cooked grain' [Zelenin 356; Kremleva 1993: 23; 2003: 525]. The dead took part in the meal, so that a place was set for him or her [Baiburin 117; Zelenin 356; Nosova 131; Kremleva 1993: 23]. Typically people did not eat with forks at the wake, since sharp objects "pricked" the soul and discouraged its presence at the feast [Kabakova 266; Nosova 94]. Baiburin [118] notes that the burial ritual was designed to remove the remains of the dead, while the pominki were designed to ensure that the soul returned to the home. Mourners began the meal by taking a piece of a blin and, after filling it with kut'ia, wishing tsarstviia nebesnogo (lit. 'heavenly realm') 'may (s)he be in heaven' to the deceased [Ananicheva and Samodelova 
190]. The meal usually ended with kisel' [Kremleva 1993: 24]. The mirrors were uncovered after the departure of the body, but the icon lamp remained lit for forty days after death [Kabakova 267]. In some areas, the bathhouse was heated for the deceased to bathe [Chistiakov 112]. In addition, a glass of water or vodka covered with bread stayed next to the icons for this period [Sedakova 244; Kabakova 268]. There was a tradition of giving food and items to the poor (both openly and secretly) in honor of the deceased for forty days [Nosova 127; Kremleva 1993: 2021].

The most important events after the burial included additional pominki on the ninth, twentieth, and fortieth days after death, and again at six and nine months, after one year, and every year thereafter [Kabakova 268; Sedakova 244; Kremleva 1993: 24-25; Firsov and Kiseleva 287]. For these rituals, relatives went to the graves for another funeral meal, women lamented, and there was often another funeral mass [Kabakova 268; Ananicheva and Samodelova 190; Zabylin 111]. Relatives left food and drink (and grain for the birds, which represent the souls of the dead in Russian lore) on the grave and then returned home for another funeral meal [Zelenin 357]. At all pominki, passersby were asked to share in the meal and to remember the deceased [Ananicheva and Samodelova 190; Kremleva 1993: 21]. The most important and largest of the commemorations were on the fortieth day and after one year, when once again the entire community gathered to commemorate the deceased at another meal. On the other days, only the family joined in the pominki. The fortieth day was particularly important since on that day the soul left the earth [Zelenin 356]. Over the course of these forty days people often visited the grave daily with food and vodka for the dead [Kabakova 268]. Kremleva [1993: 21] describes the tradition of giving away the deceased's belongings on the fortieth day. Additional commemorations occurred as part of the yearly cycle on Parents' Days, such as during Maslenitsa 'Butter Week' (the carnival period before Lent begins), during Lent itself, during Passion Week, on the Tuesday of Saint Thomas' Week (called Radonitsa 'Resurrection Day', the second week after Easter), the Saturday before Pentecost (called Sviataia Troitsa 'Holy Trinity', seven weeks after Easter), and on Saint Dmitry's Day (November 8) [Ananicheva and Samodelova 191; Nosova 135; Zelenin 356-357; Baiburin 119; Sedakova 245, 252; Zabylin 110; Nosova 135].(1)

Throughout the Soviet period, the funeral ritual typically included the following basic elements, both in Vladimir and in Novosibirsk, many 
of which were clearly preserved from the folk and religious traditions described above: a person died at home and was kept there for three days (in rare cases a person died in a hospital, but was usually brought home for the funeral for at least one night; there were exceptions if the person died a violent death, in which case he/she was generally buried from the morgue, that is the final visitation and transport for burial occurred there). A doctor came to sign the death certificate, so that the family could proceed with arrangements. When a person died, the family covered all the shiny surfaces in the home (from mirrors, to glass-fronted cabinets, to televisions). An older neighbor woman came to wash and dress the deceased. The deceased, especially women, usually had picked their funeral clothing and had it prepared in a small bundle; in the case of men, wives or children usually picked the clothing. The dress or suit could be old, that is previously worn, but the underclothing and foot wear had to be new and unworn. Once the body was prepared, it was placed in a coffin in the main room on a table. A photograph of the deceased was placed at the head of the coffin and next to it were a candle and a shot glass of vodka covered with a slice of black bread. The door remained unlocked, so that all who wished to enter and pay their respects could do so. Visitors generally brought an even number of flowers which they placed in the coffin. People maintained a vigil over the deceased for the entire time he/she was in the home. On the day of the burial, the coffin was carried out by non-blood relatives, friends or coworkers (it was considered a bad omen for blood relatives to prepare the body for burial or carry the coffin). The coffin was preceded by a procession of people carrying the coffin lid and throwing organic matter. The coffin was placed on saw horses in front of the house, so that mourners who were not attending the funeral could say farewell (in some cases it was also taken to the person's work place for the same purpose). Mourners and the coffin were transported to the graveyard in busses obtained from work or through a worker's union. At the grave site (which was already dug), there was typically a brass ensemble that played a funeral march and/or military airs and the Soviet national anthem, if the person was a veteran. Coworkers (rarely relatives) gave a eulogy and relatives kissed the person goodbye. All flowers were removed from the coffin (although artificial ones might have been left there), it was closed and lowered into the grave by cemetery workers either on ropes or on long, waffle weave towels. Each person, closest relatives first, threw a lump of dirt into the grave and everyone then waited until the grave mound was formed. Wreaths and flowers were arranged on the grave, possibly around a 
photograph of the deceased. The first ritual partaking of food occurred at the grave site and some of the food was left there for the birds. In the case of men, a shot of vodka was often left on the grave as well. The food and drink was shared with those who dug the grave as well as with mourners. The mourners returned to the family apartment, which had undergone a ritual purification. Generally a few female neighbors stayed behind to prepare for the funeral feast and also to perform this cleaning. They turned the table where the coffin had stood upside down and washed it, they mopped the path the coffin had taken, including the pod"ezd, 'entry way', opened the windows and uncovered all the mirrors. The funeral meal, pominki, included the following items: bliny, kisel' from berries or kompot from dried fruits, a grain, typically buckwheat, a main meat dish and often a soup, especially borshch or shchi; and candies. Most drank vodka, although wine was also drunk at these feasts. Toasts were offered to the deceased and stories about $\mathrm{him} / \mathrm{her}$ were told, ending with the ritual words, пусть земля будет пухом "may the earth be as down", but those present did not clink glasses. Additional pominki with visitations to the grave and the same type of meals occurred on the nineth and fortieth day, (sometimes 6 month) and 1 year anniversary after death, and for every year thereafter. In some families, an empty plate and/or glass was placed on the table for the deceased. When guests left, they were usually given candy and/or bliny to take with them to share with others, especially children, to remember the deceased. The vodka covered by black bread stayed next to the photograph for 40 days, at which point the vodka had generally evaporated, while the black bread was fed to birds.

The regional differences between Novosibirsk and Vladimir include the following: the point at which in the ritual kut'ia was eaten; the things placed/thrown before the coffin as it was carried out; distribution of goods at the burial site; rules about toasting; and limitations on the type of utensils on the table during the funeral meal. In Vladimir, kut'ia is limited to the burial site. That is, each person who attends the burial takes a spoonful of kut'ia (and perhaps a blin) at the burial site and eats it. The kut'ia is then left there on the grave. In Novosibirsk, kut'ia is served at the meal, and each person first takes a spoonful of it and a blin in memory of the deceased before eating or drinking anything else. Residents of both cities believe that organic matter should be thrown or placed before the coffin as it is carried out of the house. In Novosibirsk, flowers are thrown (often by young girls or women) before the procession. In Vladimir, fir branches are placed along the path. In 
Vladimir, it is rare to distribute items at the grave site, but in Novosibirsk, both food and objects, namely pieces of the towels used to lower the coffin and/or kerchiefs, are distributed. In Novosibirsk, informants reported that one should drink all of the first two toasts in one gulp, but that the third is sipped, since no more than three glasses should be drunk at a funeral. Novosibirskans also believe that sharp objects should not be used for the funeral meal; thus everything is eaten by hand or with spoons, which is not the case in Vladimir.

While the Soviet government espoused atheism, the funeral retained many elements that are derived from the Orthodox faith. For example, Elvira A., a retired engineer from Vladimir, described Soviet era funerals as follows:

Поэтому когда лежат дома, мы обращаемся в церковь, ищем какуюнибудь женщину чтобы почитала молитвы. Она сидит всю ночь, читает молитвы. В 1984 тоже приходили, просили чтобы почитали. Мама умерла, тоже женщина приходила читала молитвы. Мы могли немного подремать, а она сидела всю ночь, читала при свечах.

Therefore when they are at home, we turn to the church, we seek out some woman to read prayers. In 1984 they came also, we asked them to read. My mother died, a woman also came and read prayers. We could sleep a little, but she sat all night and read by candlelight.

Merridale's [264] data on funerals support this claim; while official religious figures usually did not attend a funeral (due, she claims, to the shortage of priests, not due to lack of desire for their participation), people would rely on those who remembered prayers to read or recite them. In addition, Merridale [265] also found evidence of retention of the Orthodox practice of sprinkling earth (blessed by a priest) in the shape of a cross on the coffin or the deceased's chest. Soviet Russians maintained other Orthodox practices as well: pominki at various intervals after death; inclusion of kut'ia and other traditional funerary foods in the meal, lighting candles, placing bread and vodka/water near the body and keeping it for forty days near a picture of the deceased (in lieu of an icon), and burial on the third day that included everyone throwing a handful of dirt into the grave and leaving food behind for the deceased. While it may be the case that some of these practices derived from an older, pre-Christian belief system, by the nineteenth century they had been reinterpreted as part of the Orthodox funeral service. As a result, I would argue, that people believed they were performing an 'Orthodox' rite. The association between the church and the funeral rite perservered 
throughout the Soviet period, as Olga S. noted:

в советские времена, если люди ходили в церковь, это как раз было связано с похоронами.

in the Soviet times if people went to church, it was associated precisely with funerals.

While Orthodox traditions may have been performed in the home, the Soviet policy of atheism meant that the public ceremony grew less religious over the years. In the early Soviet era, the government pushed for civil ceremonies, but a priest could still perform an otpevanie. By the 30s however, as Kremleva [2003: 530] observes, religious figures could no longer be invited to say the funeral mass; funerals were civil celebrations (at least publicly). Nevertheless, music was still considered to be a part of the ceremony, as noted above. The music itself also conveyed Soviet ideology, particularly in the case of veterans' funerals, since music dedicated to Soviet military might was played. Similarly, the concept of a eulogy at the grave site was retained. However, the performers of this practice during the Soviet period were from the work place, not from the church. In fact, much of the public ceremony, as noted, was handled by co-workers or the workers' union. One informant mentioned that her husband had the responsibility of arranging funerals for his factory colleagues. Thus, the funeral conveyed the Soviet concept of the person's contribution to society primarily as a worker, not in his/her other social roles.

Another significant issue surrounding the Soviet ceremony was the role of the community. That is, the funeral truly brought to the fore the importance of the connectedness of society. Pesman [127, 278] notes that this connectedness (the sense of svoi 'one's own') helped people to survive in the face of a difficult social system. As Boym [11, 29, 88] discusses, byt 'daily life' became the enemy of private life in the Soviet Union; it contrasted with one's spiritual being or 'real' life. Obtaining a single-family apartment, after living in a communal one, encouraged people to take refuge within the family group and to forge a sense of independence. Because the Soviet state deemphasized individualism, the family space became a place where citizens could express themselves openly. Shlapentokh [25] argues that a stable family is important to a totalitarian state, which the government recognized and thereby tried to foster through its family policies and propaganda. However, because the family can become a refuge from the state and espouse a set of values that may not correspond to state ideology, it is potentially a dangerous 
entity. The Soviet government recognized both aspects of the family and attempted to mold it as much as possible to avoid such conflicts. Verdery [61ff.] discusses how the state tried to usurp family power by taking on traditional family roles. It functioned as a "father" by doling out good to its citizens like an allowance and bestowing rewards; it functioned as a "mother" by providing services to nurture and protect the family. The government also attempted to achieve this goal by controlling ritual itself. Ultimately, as both Verdery [66] and Shlapentokh [165-166] conclude, the state could not control the family (or, I would argue, its rituals) completely, especially given the post-Stalinist trend for the family to be viewed as a refuge from state/public demands. While a similar support system was surely found in village funerals in the 19th century, which necessarily involved the entire community, the Soviet system reinforced the dependence of people upon one another to work the system, and not just to mourn their loss. It was not possible, for example, for the family to produce the amount of food required to feed the guests on their own. Thus, neighbor women would be asked, sometimes even before the death by the deceased, to provide the bliny or the kompot. Or, as one of my informants noted, it was often not possible to get the food required for a ritual meal during times of shortages; thus the system of blat 'connections' played an important role in ensuring that the funeral would be performed properly. People would rely on those who had the connections necessary to get meat, for example. In this way, the burden on the family was reduced, and social ties were reinforced. Natalia T., a professor of English from Novosibirsk, noted,

в России до 90-х годов, до коммерциализации, все держалось на родственниках и друзьях со знакомыми, абсолютно все. Кто мог, договаривался с кем-то и люди помогали....Если у тебя есть деньги, ты покупаешь все, но это больше, чем деньги. У большинства населения таких денег нет, и все равно у нас все держится на хороших отношениях, на хороших людях, друзьях и знакомых.

Before in Russia, before the 90s, before commercialization, everything is supported by relatives and friends and acquaintances, absolutely everything. If a person could, he agreed with someone, and people helped. If you have money, you buy everything, but it is more than money. The majority of the population doesn't have that kind of money and all the same, everything is supported by good relations, by good people, by friends and acquaintances.

She also noted that for her mother and father's funerals, coworkers (not just friends) were essential to the funeral ritual for support, help, and the organization of the events. 
While the funeral had been the most conservative life cycle ritual throughout the Soviet period, even it has been altered over the last decade in the post-Soviet period. The most prominent change has been the introduction of funeral service businesses. Those who arranged funerals over the last five years typically called in one of these companies to prepare the body, order the casket, and make the necessary funeral arrangements.(2) Natalia S. compared the situation in Soviet times to the current day:

приглашают специальных бабушек из своего двора или откуда-то из церкви. Они приходят, обмывают, одевают его. Сейчас, конечно, службы ритуальные есть, приглашают их, и они все делают.

they invite special older women from their courtyard or from some church; they come, wash and dress it [the body]. Now of course there are ritual services; they ask them and they do everything.

The service may remove the body from the home to the morgue or they may perform these tasks at home. For example, Tatiana U. described the latter situation:

отец умер дома. Мы заказывали службу. Они приезжали на дом, одели его, и так далее. И он две ночи был дома.

My dad died at home. We hired a service. They came to the house, dressed him, et cetera. And he was at home for two nights.

In more and more cases, the services take the body to the morgue. At this point, the person may be buried directly from the morgue or may be brought home for one night, as was done in the Soviet period if someone died in the hospital. Liudmila B. explained:

Когда он в морге, там замораживание происходит, выполняют там все процедуры и хоронят от морга. В морг приходят все провожающие. Иногда машина с покойником подъезжает к дому, где он жил, гроб выносят для того, чтобы соседи могли проститься с ним. И после этого везут на кладбище.

When it [the body] is in the morgue, the embalming happens there, they perform all the procedures and bury from the morgue. All the mourners come to the morgue. Sometimes the car with the deceased comes to the house where he lived, they carry out the coffin so that neighbors can say farewell to him. And then they take it to the cemetery. 
Other informants said that it is important for the deceased to spend at least one night at home, even if $\mathrm{s} / \mathrm{he}$ was taken to the morgue by the funeral service or died in a hospital. Marina K. reported:

Принято, что когда покойного забирают из морга, надо чтобы ночь он был дома. Гроб ставят дома головой к окну, ногами к дверям. Ставят свечки, наливают воду, на стакан с водой кладут кусочек хлеба. Считается, что душа его где-то здесь витает. Или водку наливают. Кто как - кто воду, кто водку.

It is the norm that when they collect the deceased from the morgue, it is necessary for him to be home one night. They set the coffin up at home with the head toward the window, legs toward the doors. They place candles, pour water, on the glass with the water they put a piece of bread. It is thought that the soul is hovering around somewhere. Or they pour vodka. Either way, some water, some vodka.

However, it is clear that there has been a shift, so that death is more removed from the family circle. While there are many factors involved, (including the age of the deceased, family tradition and financial concerns) funeral businesses have become the norm, rather than the exception, over the last decade.

Another common change is shifting the funeral meal to outside the home. For example, Aleksandr U. said that "сейчас очень редко делают дома" (now they don't do them [pominki] at home). His wife added that while the pominki on the ninth and the fortieth days might still be at home, those on the day of the funeral are often at a stolovaia 'cafeteria'. Elena P. expressed similar sentiments:

Мы заказывали. У мамы было в столовой...Как по деньгам. У кого сколько денег, кто как может, тот так и делает. Если есть кому готовить, это же много народу приходит, надо готовить заранее. Неудобно готовить, если в комнате рядом покойник лежит, и тут же готовят...Лучше, чтобы этого не было.

We ordered [the meal]. We had mom's in a cafeteria...It depends on money. How much money someone has, however much one can manage, that's what one does. If there is someone to cook, after all lots of people come; you have to cook in advance. It is uncomfortable to cook if the deceased is lying in the next room...It is better not to have it that way.

While this change does make it easier for people, since they do not have to prepare a meal for large numbers of mourners, it also is a significant alteration in the attitude toward the funeral. As Elena's comment shows, money is now a primary concern in the funeral; it has become associated 
with the consumer economy. In some ways these developments make things easier for the family, as these informants have noted, but in other ways the role of finances in the funeral complicates matters, both for the individual and for the society at large.

The economic situation has caused some concern among my informants, particularly older ones. With inflation and the economic crises in recent years, those who had saved for their funerals, to help their children, now think they will not be able to afford a proper burial. Klara K., for example, said that she had a good savings account for that purpose, but the currency revaluation and inflation had reduced her life savings to nothing. She was concerned that this would place an undue burden on her family when she died. Many people made reference to the expense surrounding a funeral (a factor also in the Soviet period certainly); Merridale [341] also discusses how her informants were worried about the expense of a funeral. As a result, contributing to the funeral fund has become a important role for mourners. While people always helped financially in Soviet Russia, more informants in the postSoviet period reported that they gave money (and not other kinds of help, such as cooking or making arrangements) to the relatives of the deceased.

Funerals certainly cost money in the Soviet period as well. One did not have had to pay for a burial plot, but one did have to pay for the funeral meals, the coffin, give items or cash to people who prepared the body and dug the grave and so forth. However, there now seems to be a different attitude toward funeral expenses. A two-tiered system has been created in the post-Soviet world. Families who can pay more have an easier time, since the funeral service and the cafeterias provide support for them that families of more modest means cannot afford. As a result they still have to rely on friends and family to have a proper burial. Aleksandr U. expressed his opinion of the current situation succinctly:

а сейчас если платишь, то все приедут, даже целый автопарк.

and now, if you pay, everyone will come, even a whole automobile lot.

People can no longer rely on employers and the state to help with funeral expenses;(3) in the post-Soviet world the situation has become one that emphasizes the divide between people, between those who have thrived in the consumer economy and those who have not.

One change that indicates the greater social flexibility is the reintroduction of religion in the funeral rite. Most of my informants 
mentioned post-Soviet changes in connection to religion. While, as I have discussed, there were often some religious components to funerals during the Soviet period, they were often hidden within the home. Certainly a funeral mass at the graveside was generally not an option. Nor were openly religious items buried with the corpse. However, the religious practices in the funeral were better preserved than in other life cycle rituals. Since the fall of the Soviet Union, funerals have become more and more religious, not surprisingly, given these traditional attitudes. In fact, it does not seem to matter (unlike with baptism and marriage) whether people were themselves religious or not; the funeral is often Orthodox regardless. Tatiana D. described just such a situation:

Когда тетю хоронили, она никогда не верила в Бога, ее подруги сказали, что нужно священника пригласить. И мы приглашали священника домой. Это интересно, я сама в первый раз видела как отпевают, именно здесь, перед тем как похоронить.

When we buried my aunt, she never believed in God, yet her friends said that we had to invite a priest. And we invited a priest to the house. It is interesting. I myself saw how they peform the funeral mass, right here, before they bury [someone].

Religious funeral rites may occur, as in this case, at the home, or people might take the deceased to the church before burial. In rare instances, the priest may come to the graveside. Aleksandr U. noted that the priest may say the mass at home and also go to the cemetery. Nina S. described one funeral that she had recently attended that had a full religious service:

У Евгения Павловича мы пришли домой, лежит много цветов, пять венков. В руке он держит иконку, и у изголовья горят две свечи. И лампадка горит. Его повезли из дома в тот дом, который он строил собственными руками недалеко от Владимира....Там его снова выгрузили из машины, на которой везли, положили на табуретки и работник культа, то ли священник, то ли поп, начал заупокойную молитву. Он что-то читал, потом вместе с другим мужчиной, они что-то пели. Потом ходили с кадилом вокруг гроба. Это было минут сорок. Потом снова его в машину, в катафалк, и поехали в церковь. В церкви поставили гроб на определенное место, где отпевают покойника, опять заупокойная служба по умершему.

For Evgeny Pavlovich we went to the home, there are many flowers, five wreaths. In his hand he is holding a small icon and at his head two candles are burning. And a lamp is lit. They took him from his house to the house which he built with his own hands near Vladimir... There they unloaded him from the car in which they were transporting him, put him on stools, and a religious worker, either a Catholic priest or an Orthodox one, began the 
prayer for the dead. He read something, then together with another man, they sang something. Then they walked around the coffin with a censer. That took about forty minutes. Then once again they put him into the car, into the hearse, and we went to the church. At the church they put the coffin in the designated place where they say the mass for the dead, once again a funeral service for the dead.

Some aspects of the otpevanie ritual were preserved in families during the Soviet period, such as sprinkling a cross of dirt on the deceased's chest. However, now the priest openly performs all these rituals, as Ekaterina Z. related:

Батюшка читает молитвы, кадит. Хор ему подпевает. Потом он говорит напутственное слово обязательно. Это уже зависит от того, кто умер, кто присутствует. Обычно это утешительно действует на людей. Я знаю, что батюшка вкладывает грамотку такую, разрешительную молитву...Там батюшка освящает землю и этой землей посыпает крестообразно.

The father [here a religious title] reads, prays, censes. The choir sings in response to him. Then he obligatorily says parting words. This depends on who died and who is present. Usually it has a comforting effect on people. I know that the father puts in a type of note, a prayer of absolution... The father blesses earth and then sprinkles it in the shape of a cross.

Other religious markers that informants named include a religious text in the coffin (Bible, prayers, psalter), a band with a prayer on the deceased's forehead and a lit candle in his/her hands.

Liudmila B., who was born in 1932, said that the resurgence in religious ritual causes some concern for people of her age:

Вообще в последнее время больше следуют нашим традициям православным, больше стараются им следовать, потому что мы где-то что-то мы потеряли...Сейчас стараются восстановиться. Это трудно. Люди нашего круга, мы тоже не все знаем, не все умеем, иногда делаем не так наверное, как это нужно сделать. Хотя мы хотим сделать так, чтобы отвечало традициям, верованиям нашего народа. Сами мы воспитанные вне этих традиций. Мы не воинствующие безбожники, но мы воспитаны так, что нет. Мы стараемся познать, узнать...Мы столько лет прожили без этого всего, и как трудно к этому прийти.

In general recently they follow our Orthodox traditions more; they try to observe them more, because we lost something somewhere... Now they are trying to revive them. It is hard. People of our circle, we also don't know everything, can't do everything, sometimes probably do things not how they should be done. But we want to observe tradition, the faith of our people. We ourselves were raised outside of these traditions. We are not fervent atheists, 
but we were raised that there was no God. We try to know, to learn...We lived for so many years without all that, and it is so hard to come to it.

Given that it is important for both the repose of the soul and for the living to have a proper burial, these concerns are serious; if one performs the ritual improperly, then it fails to achieve the goals of the ritual. Even if people do not know why they perform these rites, they continue to do them anyway, Liuba S. explained:

за много лет советской власти вытравлено как себя вести, но какие-то передаются, и в критические моменты люди старались выполнить так, как положено, как было завещано раньше. Может быть это не совсем понятно, но так принято и все, так делают.

over many years of Soviet rule proper behavior was destroyed, but some things are passed on and in critical moments people tried to perform as they should, as was once bequeathed. Maybe it is not really understood, but that is the way it is done and that's it, they do it that way.

The return of religious aspects of the ritual is both a comfort and a source of anxiety. In addition to such concerns, people also expressed dismay that the return of Orthodoxy actually adds to the expense of the funeral. Aleksandr K., for example, said they did not have a mass, because they did not have the money to pay for a priest. In this sense, the return of the church is connected not only to lost tradition, but also to the consumer economy. For the church to survive, of course, it must have funds, funds provided by donations for funeral masses and prayers among them.

The changes in the funeral practices throughout the 20th and 21st centuries reflect the social norms of the period. While certain traditional elements were considered to be essential for the soul of the deceased and the family to be at peace after death, other messages are also conveyed by the funerary behaviors. During the Soviet period, the focus on the deceased as a worker before all else was a major component of the funeral. This concept endures to some extent even now, since most postSoviet funerals involve a eulogy by coworkers. However, that public message was balanced by the private ceremonies that focused on the social networks Soviet Russians built to survive in their society; on the sense of interdependence that they shared in order to endure both personal grief and social trials. Thus the official message was less strong than the social unity promoted by a funeral. In the post-Soviet world, the importance of monetary concerns and distancing oneself from the Soviet world view are both seen in the funeral. As a result, people have rejected behaviors particularly associated with the Soviet Union, e.g., the brass 
band at the funeral, to distance themselves from Soviet ideology; nevertheless they are not yet fully comfortable with the expenses necessitated by the contemporary funeral. It remains to be seen what the long-term effects of these changes will bring and whether the promotion of social unity and interdependence endure as a major component of the post-Soviet funeral ritual.

\section{NOTES}

1 People did welcome the return of the dead, both in dreams and for pominki, particularly when they gave advice to the living, and at yearly cycle rituals [Nosova 139-140; Baiburin 119; Chistiakov 112; Kremleva 1993: 24-25; Kabakova 272]. However, there was always a danger that the dead were unhappy if they returned, because the burial had not been done properly [Sedakova 245; Razumova 108]. If this were the case, then the living could try to appease the dead either by digging a hole at the grave and putting objects the deceased requested in a dream, or by putting objects into another person's coffin. Similarly, the living also requested that the deceased take messages to other dead souls [Kremleva 1993: 18-19].

2 At the same time they also depended on the family. Some who arranged funerals during this time still maintained the Soviet traditions of burying from home and having family and friends do everything. I would note, however, that this was generally the norm when senior citizens died. Those who died at a younger age often were prepared for burial by a funeral company.

3 The state still does bury veterans at its own expense. Two informants had state support for the funerals of their relatives who were World War II veterans during this period.

\section{BIBLIOGRAPHY}

Aleksandrov, V. A., I. V. Vlasova and N. S. Polishchuk, eds. 2003. Russkie. Moscow: Nauka.

Ananicheva, T. M., and E. A. Samodelova. 1997 Obriady $i$ obriadovyi fol'klor. Moscow: Nasledie.

Baiburin, A. K. 1993. Ritual v traditsionnoi kul'ture. Strukturnosemanticheskii analiz vostochnoslavianskikh obriadov. Saint Petersburg: Nauka.

Boym, Svetlana. 1994. Common Places: Mythologies of Everyday 
Life in Russia. Cambridge, MA: Harvard University Press.

Chistiakov, V. A. "Predstavleniia o doroge $\mathrm{v}$ zagrobnyi mir $\mathrm{v}$ russkikh pokhoronnykh prichitaniiakh XIX-XX vv." In Sokolova. 114127.

Crone, Anna Lisa, and Catherine V. Chvany, eds. 1996. New Studies in Russian Language and Literature. Columbus, OH: Slavica.

Firsov, B. M., and I. G. Kiseleva, eds. 1993. Byt velikorusskikh krest'ian-zemlepashtsev. Opisanie materialov etnograficheskogo biuro kniazia V. N. Tenisheva. Saint Petersburg: Izdatel'stvo Evropeiskogo doma.

Ivanov V. V., and L. G. Nevskaia, eds. 1990. Issledovaniia $v$ oblasti balto-slavianskoi dukhovnoi kul'tury. Pogrebal'nyi obriad. Moscow: Nauka.

Kabakova, G. I. 2001. Antropologiia zhenskogo tela v slavianskoi traditsii. Moscow: Ladomir.

Kremleva, I. A. "Pokhoronno-pominal'nye obriady u russkikh. Traditsii i sovremennost'." In Simchenko and Tishkov. 8-47.

---- "Pokhoronno-pominal'nye obychai i obriady." In Aleksandrov, et al. 517-532.

Mahler, Elsa. 1935. Die russische Totenklage: Ihre rituelle und dichterische Deutung. Leipzig: Veröffenlichungen des slawischen Institut.

Merridale, Catherine. 2000. Night of Stone: Death and Memory in $20^{\text {th }}$ Century Russia. New York: Viking.

Moyle, Natalie K. "Mermaids (Rusalki) and Russian Beliefs about Women." In Crone and Chvany. 221-238.

Nosova, G.A. "Russkii traditsionnyi pokhoronnyi obriad: sovremennye formy." In Simchenko and Tishkov. 84-122.

Pesman, Dale. 2000. Russia and Soul. Ithaca, NY: Cornell University Press.

Razumova, I. A. 2001. Potaennoe znanie sovremennoi russkoi sem'i. Moscow: Indrik.

Sedakova, O. A. 2004. Poetika obriada. Pogrebal'naia obriadnost' vostochnykh i iuzhnykh slavian. Moscow: Indrik.

Shlapentokh, Vladimir. 1984. Love, Marriage and Friendship in the Soviet Union. Ideals and Practices. New York: Praeger.

Simchenko Iu. B. and V. A. Tishkov, eds. 1993. Pokhoronnopominal'nye obychai i obriady. Moscow: Institute for Ethnography and Anthropology.

Sokolova, V. K., ed. 1982. Obriady i obriadovyi fol'klor. Moscow: 
Nauka.

Surkhasko, Iu. Iu. 1985. Semeinye obriady $i$ verovaniia karel: konets $X I X$-nachalo $X X$ v. Leningrad: Nauka.

Tolstoi, N. I. "Perevorachivanie predmetov v slavianskom pogrebal'nom obriade." In Ivanov and Nevskaia. 119-128.

Verdery, Katherine. 1996. What was Socialism and What Comes Next. Princeton, NJ: Princeton University Press.

Zabylin M. 1990. Russkii narod. Ego obychai, obriady, predaniia, sueveriia i poeziia. [1880] Moscow: Kniga Printshop.

Zelenin, D. K. 1991 (1927). Vostochnoslavianskaia etnografiia. ( K. V. Chistov, ed. K. D. Tsivina, trans. Moscow: Nauka.

\section{INTERVIEWS CITED}

Aleksandr K., engineer-inspector, DOB 1945, native of Archangelsk, interviewed 6/12/03 in Novosibirsk.

Aleksandr U., engineer, DOB 1948, native of Kaliningrad, interviewed 6/9/04 in Vladimir. Ekaterina Z., musician, DOB 1978, native of Novosibirsk, interviewed 6/2/04 in Novosibirsk.

Elena P., kindergarten teacher, DOB 1971, native of Vladimir, interviewed 6/30/03 in Vladimir.

El'vira A., engineer, DOB 1938, native of Vladimir, interviewed $7 / 7 / 03$ in Vladimir.

Klara K., insurance agent, DOB 1935, native of Ufa, interviewed 3/14/01 in Novosibirsk.

Lidia C., English teacher, DOB 1956, native of Novosibirsk, inteviewed 4/20/01 and 6/18/03 in Novosibirsk.

Liuba S., art teacher, DOB 1954, native of Petrovskii Zavod, interviewed 5/11/01 and 6/25/03 in Novosibirsk.

Liudmila B., teacher, DOB 1932, native of Kovrov, interviewed 7/10/03 in Vladimir.

Marina K., secretary, DOB 1974, native of Novosibirsk, interviewed $4 / 21 / 01$ and $6 / 11 / 03$ in Novosibirsk.

Natalia S., engineer, DOB 1954, native of Vladimir, interviewed 6/9/04 in Vladimir.

Natalia T., university professor, DOB 1954, native of Novosibirsk, interviewed 5/28/01 and 6/23/03 in Novosibirsk.

Nina S., engineer, DOB 1930, native of Vladimir, interviewed 7/10/03 in Vladimir.

Olga S., graduate student (statistics), DOB 1976, native of 
Voronezh, interviewed 7/14/04 in Lexington, KY.

Tatiana D., private school teacher, DOB 1953, native of Vladimir, interviewed 6/30/97 and 6/2/03 in Vladimir.

Tatiana U., accountant, DOB 1948, native of Vladivostok, interviewed 6/9/04 in Vladimir. 